\title{
Skin Abscess
}

National Cancer Institute

\section{Source}

National Cancer Institute. Skin Abscess. NCI Thesaurus. Code C99093.

An abscess that develops in the skin and subcutaneous tissues. Causes include folliculitis, furuncle, skin injury, and bacterial infections. Signs and symptoms include the presence of a swollen, tender, and erythematous nodular lesion in the skin associated with fever and chills. 